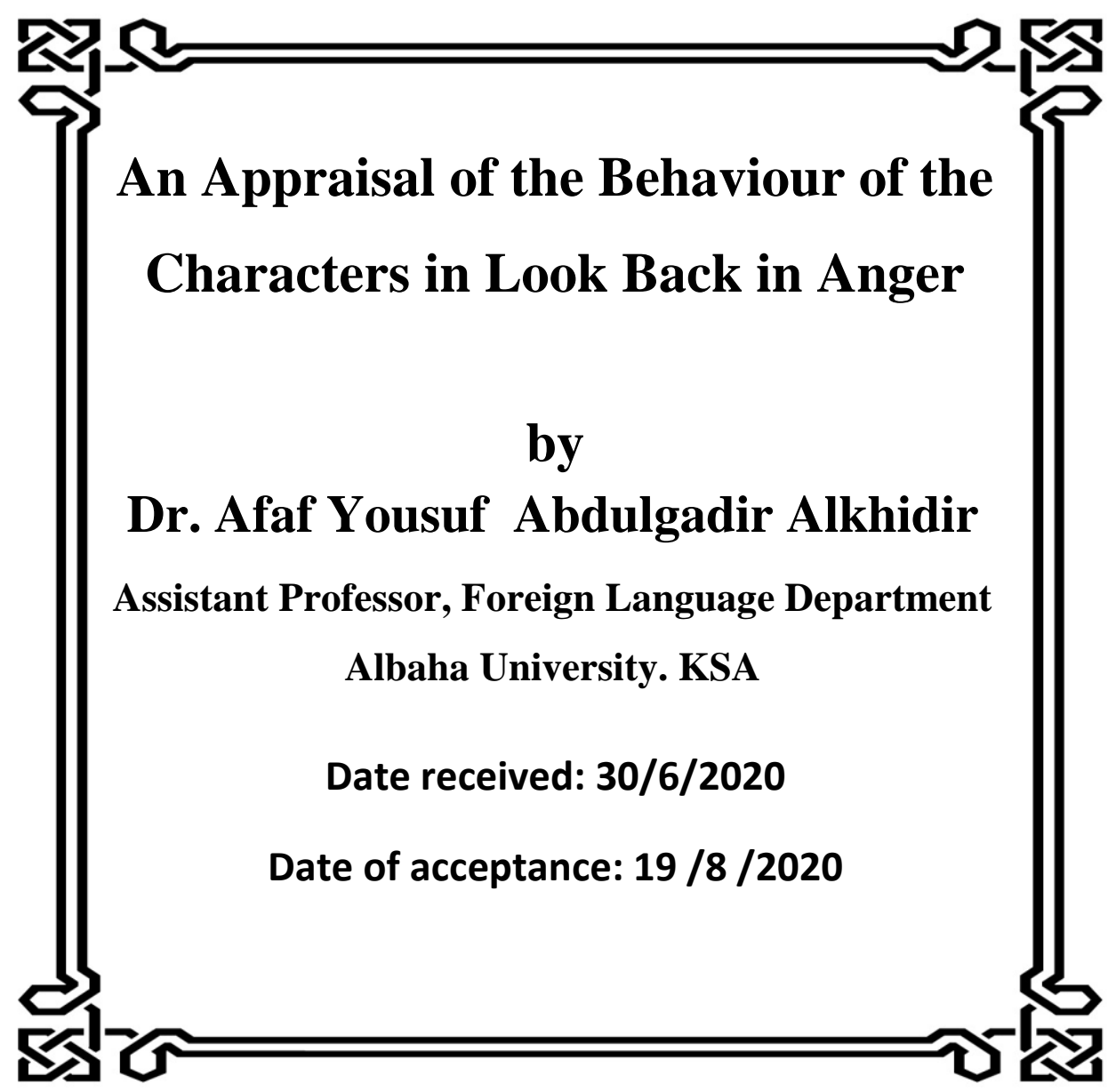





\section{An Appraisal of the Behaviour of the Characters in Look Back in Anger}

\section{Abstract:}

The characters in 'Look Back in Anger' are either the generation of post World War II when Britain had lost her power and glory and was relying for economic recovery on USA or the previous era. Along with the futile win of 1945 Britain decreased its identity as an imperial power. This era was named as the era of 'angry young man'. The generation of this era is reflecting disillusionment, rebelliousness and uncertainty. The characters in the play are representing the generation of this era and the previous era. Current generation characters are confused and frustrated as they had the impact of two major revolutions like democracy and technology. However, colonel Redfern, the representative of the previous generation was living in the past glory of England. The transitory period, cultural differences, and class identities are reflected from the behaviour and the utterances of the characters which makes Osborn's 'Look Back in Anger' a unique play in the history of drama in England.

إن الثخصيات في مسرحية " أنظر إلى الوراء بغضب " هي إما جيل ما بعد الحرب

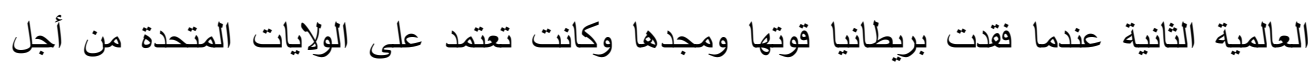

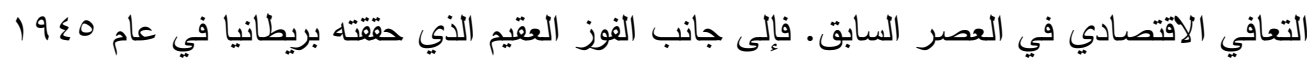
تتاقصت هويتها باعتبارها قوة إمبريالية. وسميت هذه الحقبة بعصر 'الثاب الغاضب'. إن جيل هذا العصر يعكس خيبة الأمل والتمرد وعدم اليقين. الثخصيات في المسرحية تمثل جيل هذه الحقبة والحقبة السابقة. الواقع أن شخصيات الجيل الحالي مشوشة ومحبطة بسبب تأثرها بثورتين رئيسيتين مثل الديمقراطية والتكنولوجيا. غير أن العقيد ردفرن، ممثل الجيل السابق، كان يعيش في مجد إنكلترا في الماضي. وتتعكس الفترة الإنتقالية والاختلافات الثقافية والهويات الطبقية في سلوك الثخصيات وأقوالها التي تجعل مسرحية أوزبورن ' أنظرة إلى الوراء بغضب' مسرحية فريدة في تاريخ الدراما في إنجلترا. 


\section{Introduction}

Martin Hollins said, "Human Beings are self-conscious, rational and creative. We can fall in love, write sonnets or plan for tomorrow. We are capable of faith, hope and charity and for that matter, of envy, hatred and malice." This is human nature which reflects his characteristic qualities that make human beings different from each other. Samuel Umen an American philosopher has described different types of nature in his book 'Imagery of Men', "He is compassionate, generous, living and forgiving, but also cruel, vengeful, selfish and vindictive."

The behaviour of the human being is changed eventually because of the impact of the incidents what he is confronted of. It is not the case of the chance of his birth. French philosopher Jean Paul Sartre has said in his book, 'Existentialism And Human Emotions', "...First of all, man exists, turns up, appears on the scene, and only afterward defines himself." But, the behavior is a continuous changing process. It is said of course, that the past incidents influence the behavior of the individual. This is clearly depicted in the play 'Look Back in Anger' by Osborne.

Look Back in Anger (1956) is a reality play written by John Osborne. It is his first renowned presentation as a playwright. It is evident that Osborne got the idea from his personal life and failing marriage with Pamela Lane while writing 
Look Back in Anger. The play was pronounced the term "angry young men" to describe Osborne and those of his generation who presented the severity of realism in the theatre in contrast to the more escapist theatre that characterised the previous generation. This harsh realism was depicted in Look Back in Anger and was acknowledged as kitchen sink drama in theatre.

The play focuses on the life and marital struggles of an intelligent and educated but dissatisfied young man of workingclass origin, Jimmy Porter, and his equally competent yet inexpressive upper-middle-class wife Alison. The other characters including Cliff Lewis, an amiable Welsh lodger who attempts to keep the peace; and Helena Charles, Alison's snobbish friend. All incidents and events of the play are moving around these characters. Jimmy, the protagonist of the play is somewhat complicated. He is an "Angry Young Man" who is not happy with his life and society. The story of the play reflects his unhappiness with the people and things around him. However, all the characters are simple and understanding.

In Look Back in Anger, the characters are different from the contemporary characters. Their expression and the language are so real that one is compelled to believe its match with the real life situation. The characters are very much close to the generation of the post second world war period who are confused, frustrating 


\section{Dr. Afaf Yousuf Abdulgadir Alkhidir}

and full of uncertainty. They are the victim of the era which is reflected from their behavior.

The characters in the play belong to different social classes. Alison and father are from upper-middle class, Helena from the middle, Jimmy and Cliff from the working class. The presence of Alison's father Colonel Redfern is useful to show the differences with other people and is an icon of generation gap. As said before, the main character is Jimmy Porter. He becomes the voice of the young generation of after-war England because he expresses not only their way of thinking and their ideals of rebels, but also their frustrations and their awareness of a deluding present.

"Look Back in Anger" (1956) was a different kind of play. It looked as it was against the traditional British theatre. According to the critic of the New Stateman and Nation "Look Back in Anger" was not perfect but it was full of excitement and life. He said it is an address to you if you are young and even it will help you in understanding the feelings of young. Judie Dench, Maureen Paton, Daily Express June 8, 1989 were of the opinion that "Look Back in Anger" is a good attempt to discuss relationship of husband and wife in a different way. The "Good plays change meaning with time". Micheal Billington, June 8, 1989 stated that it is an expression of personal gain more than a social play. 
Barker, The Daily Express May 9, 1956, gave his opinion about the play as it was "intense, angry, feverish and undisciplined". It was even crazy bit he called it repeatedly young for three times. Tynan, May 13, 1956 also called it a good young drama of his age. Million Shulman, The Evening Standard May 9, 1956 was of the opinion that Look Back in Anger is a "dispraising Cry" but have only a position of self-pitying snivel.(Falak Naaz \& Anila Jameel, 2015).

Cecil Wilson gave the term "Young Neurotic" to Jimmy in Daily Mail, May 9, 1956 and wrote about the character of Jimmy who lives like a pig and his "bitterness produces a fine flow of savage talk". He further added that Porter's personality was complex because the play had given no main explanation of his behaviour. His attitude was boring because it was difficult to explain it.

The dissatisfaction of the young generation who are fed up with the social injustice and the continuity of rigid class privileges and were frustrated with the stagnation of the economic and intellectual life of Britain is very well expressed through the behaviour of the characters in the play. 


\section{Methodology And Analysis}

Jimmy Porter: Jimmy Porter, a twenty-five-year-old man who lives in Britain's industrial midlands. An educated, well-read individual, Jimmy works in a factory, tends a sweet-stall he is trying to buy, and issues diatribes about British society, which he feels has denied him opportunity simply because of his workingclass background. Jimmy prides himself on his honesty, but he can be cruel, as is seen in his verbal attacks on his wife, Alison, and on his friend Cliff Lewis, who lives with them. Jimmy excuses himself for mistreating Alison by insisting that she is too possessive and that she cannot understand him because she has never suffered, as he suffered when, at the age of ten, he had to watch his father die.

Look Back in Anger is full of Jimmy's monologues and the playwright has created his character thoughtfully. Critic John Mander (1961), also says: "The author invested so much of his thought and experience and energy in the person of Jimmy that he had little over for the other characters."

Jimmy the protagonist expresses his anger through the use of language that could be almost considered biblical. Jimmy uses the word "blood" throughout the play to describe his relationships. "Blood" signifies sacrifice and violence. Jimmy feels as though he 
has sacrificed much of his life to a lifeless relationship with Alison. Jimmy feels he has shed his blood for his dull domestic life. He also has a violent attitude towards Alison. Though there is no any depiction of real physical violence in the play, Frequent use of the word "blood" demonstrates the deep psychological violence that both Allison and Jimmy had for each other.

"One day, when I'm not longer spending my days running a sweet-stall, I may write a book about us all. ...It'll be recollected in fire, and blood. My blood." (Look Back in Anger, 54.)

But on the other hand, Jimmy seems to live in his pain of standing alone beside his dying father and Mrs. Tanner. There is a sense of bitter satisfaction, even pride in his lonely visits with death, as he claims "I was the only one with her" (Malik, Look Back in Anger 63), referring to Mrs. Tanner's deathbed. In the words of John Russell Taylor, (1978), "Jimmy Porter is the self flagellating solitary in self - inflicted exile from the world, drawing strength from his own weakness and joy from his own misery."

However, Jimmy is aware of the fact that while he is rich, he does not have the necessary knowledge and values to become an upper-class as he himself indicates in the work: "It's true my father was a peasant, but here am I in my white waistcoat and 


\section{Dr. Afaf Yousuf Abdulgadir Alkhidir}

brown boots, barging in like a bull in a china shop. The only thing is, I am rich. I have plenty of money, but when you really get down to it. I'm just another country bumpkin. .... I was reading this book and couldn't make sense of it.” (1998, I. 241)

All he could feel was ,the despair and the bitterness, the sweet, sickly smell of a dying man'. He learnt at an early age ,What it was to be angry-angry and helpless ${ }^{e}$. His suffering is profoundly solitary experience and Jimmy knows it and says to Alison: ,...the heaviest, strongest creatures in the world seem to be the loneliest. Like the old bear, following his own breath in the dark forest. There's no warm pack, no herd to comfort him. That voice that cries out doesn't have to be a weakling 's' (LBA 94)

Jimmy is longing for the company of anyone to whom he can express his ideas and feelings regarding society, religion causing frustration, disillusionment and nihilism in him. In his search for identity and existence he has only sufferings and pains. Jimmy hates the upper class in spite of it that his mother and his wife's relatives are "Pretty Posh". Jimmy Porter blames class and status system of society for making his existence and identity meaningless. He likes Cliff only because he (Cliff) calls himself a "common man". He says to Nigel, the brother of Alison, "You are never heard so many well-bred common places coming from beneath the same bowler hat" (LBA). 
Jimmy tortures his wife continuously. He has a revengeful feeling for upper middle class and his wife Alison is from the same class. He feels that the people of this class are shallow and have no emotions for working class people. Therefore, he is almost a fanatic in conversation with her. Helena Charles's remark in Oborne's Play Look Back in Anger on Jimmy's behaviour was "In fact his sado-masochist trend makes him out to be almost a fanatic of sorts whose mindless brutality is single mindedly directed towards his quiet wife, Alison."

But his abuse of Alison is purely sadistic, as he amuses himself by seeing how much abuse she can take. At one point of time Jimmy shows his outburst: "Perhaps, one day, you may want to come back. I want to be there when you grovel ... I want to watch it”. Thus, he exhibits his unusual as well as childish nature with whom few wives will be able to cope with.

Jimmy wants others to partake his suffering. But his wife is highly ironical about him: "Don't take his suffering away from him. He'd be lost without it" (LBA 54).

Alison Porter: Alison Porter, Jimmy's wife. A woman of upper-middle-class background, she is perceptive enough to understand that her husband resents everything in her that reminds him of the social differences between them. After three years of 


\section{Dr. Afaf Yousuf Abdulgadir Alkhidir}

marriage, she is miserable. The only way that she can survive Jimmy's constant verbal attacks on her and on her family is to conceal her feelings and remain silent is definitely one of the most striking qualities that is attributed to Alison is her tolerance.

Alison is Jimmy's age (Salma Haque 2014), and is tall, slim and dark. Moreover, she has a sorrowful look which indicates her unhappy state. There are also hints in the opening scene that crisis has been making its place in their house without sufficient money and peace and she is getting burnt slowly. Her parental house was just like an Eden compared to her new one. Actually, Jimmy's house is unable to provide everything an upper-class daughter could possibly want as he cannot realize that he has a wife and it is his obligation to support her financially as well as mentally.

Alison becomes the victim of Jimmy's cruelty and is always in great miseries. For this there is no healthy atmosphere in their house. Critic Taylor also suggests that "The principal sufferer from all this is his wife Alison, whom he cannot forgive for her upper-middle class background and whom he constantly torments in order to extract some reaction from her ..." (Taylor, 41)

But, Alison hardly loses temper in spite of Jimmy's nonstop offensive criticism towards her. Her silence also angers him greatly which is the result of his incessant talking and he is 


\section{An Appraisal of the Behaviour of the Characters}

in Look Back in Anger

unaware of its cause. Hence, he sarcastically calls her "monument to non-attachment" and tells Cliff: "Nothing I could do would provoke her"(LBA, 14). Jimmy cannot understand that her silence is unnatural and rather forced by him as she shares warm bond with Cliff who also belongs to Jimmyee class. In her words: "If things have worked out with Cliff, it's because he's kind and lovable ..."

Alison's pre-marital life was without any responsibility and tension. Contradictorily, in her married life she is in poverty which is a new experience in her life. She has to perform all the household chores, cannot unburden herself to her husband, cannot mix with her family, has no recreation and has to lead a monotonous life. Moreover, she is pregnant and both mental and physical pressures mount.

Alison is cultured, well-bred, and possesses the grace and bearing of a mild woman unworthy of the fighting of Jimmy and he never takes her pleas for a little peace seriously; rather curses her: "I wish you could have a child, and it would die"(LBA, 36). It seems her serenity is at the mercy of him. Even Cliff consoles her seeing her dilemma: “He's being offensive. And it's so easy for him" (LBA, 7). 


\section{Dr. Afaf Yousuf Abdulgadir Alkhidir}

When he accidentally burns her arm, he goes into another room for fear of getting criticized by her rather than pacifying her. Therefore, he aggravates her agony. The total situation is puzzling for her as she has married for love and was unprepared for his vituperation. Thus, she suffers much. Jimmy is ignorant of them as she never verbalizes her feelings and has to take refuge in her ironing and silence.

Alison though not evil or possessing morally negative qualities, remains hollow till she loses her child. Alison's miscarriage was as if Providence's intervention, their punishment for not treating their marriage with respect, for Jimmy's vulgarity and vitriolic comments, and Alison's indifference to it all, or maybe because she had failed to rid this world of sterility owing to her virgin state of being.

Cliff Lewis: Cliff Lewis, a friend of Jimmy, also from the working class. A gentle person, he does not have Jimmy's fire or his wit, but he also lacks his cruelty. Cliff is genuinely fond of Alison. He shows his appreciation for her housekeeping efforts, and he tries to defend her from Jimmy's verbal abuse. It is he, not Jimmy, who bandages Alison's arm after she burns it. 
Cliff says to Alison: "I suppose he and I think the same about a lot of things, because we're alike in some ways. We both come from working people (LBA). Oh I know some of his mother's relatives are pretty posh, but he hates them as much as he hates yours. Don't quite know why. Anyway, he gets on with me because I'm common." (195, I. 27) What Cliff highlights is that Jimmy shows his hatred and anger towards the upper middle class, whereas he can get on well with the ordinary working class people.

Cliff is also worried about her gloom and tells her: " $I^{\text {ee }} \mathrm{m}$ wondering how much longer I can go on watching you two are tearing the insides out of each other" (LBA 24)

Cliff is a sensible friend of Jimmy and Alison. He understands the mental situation of both of them. He knows the reason of Jimmy's behaviour with Alison. He doesn't like what Jimmy does with Alison. He wants to give comfort to Alison. He wants to get them out from this mental trauma. Helena considers Cliff as a good friend and she tells him about her pregnancy.

Helena Charles: Helena Charles, a beautiful, elegant actress, a friend of Alison and a member of her social circle. Helena comes to spend a few days with the Porters, but, finding herself increasingly attracted to Jimmy, she stays on, intent on 


\section{Dr. Afaf Yousuf Abdulgadir Alkhidir}

driving a wedge between Jimmy and Alison. As Alison's confidant, Helena urges her to face up to Jimmy or to leave him; meanwhile, she increases the pressure by wiring Alison's father to come for her.

Moreover, Helena is more mature and experienced than Alison. She tells Helena that for twenty years she had lived a happy, uncomplicated life, and suddenly thereafter this spiritual barbarian has stormed into her life and has thrown a challenge at her. She also mentions that earlier the opposition of her parents to the relationship crystallized her own strong feelings for Jimmy, and made up her mind to marry him.

Helena says about Jimmy Porter. "I feel he thinks he's still in the middle of the French revolution and that is where he ought to be, of course" She adds; "he does not know where he is or where he's going. He will never do anything and he'll never amount to anything". He was frustrated because he was born out of his time, in a complete static and hostile unjust society. He fails to find a way or someone. (Falak Naaz \& Aneela Jameel, 2015).

It is Helena who tries to put Jimmy in his place when Jimmy takes this situation to an unbearable level in wishing death to Alison's mother and says, "You've no right to talk about her mother like that" but fails to stop him as his provocation is constant knowing the weakness of his opponent. 
Alison's arrival is sudden and similarly Helena's departure is also quite unexpected to both the readers and critics. Alison could not think that her friend would give up as easily as she has been informed through letter by Helena that she loves Jimmy. On the other hand, Helena's decision to go makes Jimmy furious with her. $\mathrm{He}$ considers her decision as an escape from life and he says: "They all want to escape from the pain of being alive. And, most of all, from love." (LBA 24)

Even after the arrival of his wife he makes no attempt to conceal his contempt for her. He is rather rude in his attitude to her and says to Helena: "What are you looking so solemn about? What's she doing here?" (LBA 25) This is the proof of his preference for Helena to Alison. His remarks are very shocking to any wife especially after the loss of an unborn baby. Helena could have taken advantage of his preferential treatment to her. But, we see she suffers from mental agony when Alison returns. She would have lowered her dignity if she had continued her relationship with Jimmy by staying with him in this crucial moment of Alison's life. By her departure in Act III, scene II, she shows her dignity, honesty, and judicious discretion, which only a good human being possesses. 


\section{Dr. Afaf Yousuf Abdulgadir Alkhidir}

She also proves herself to be a true friend to Alison and shows that outwardly she looks modern but inwardly she is like all typical women who get affected by the distress of their fellows and cannot go beyond their middle class conviction. Thus, Helena's arrival and departure are vital to the structure of the play. She acts as an instrument in bringing the estranged couple together. Because of her arrival and interference (Salma Haque 2007), Alison once leaves her husband and Alison's unexpected entrance brings about an abrupt and revolutionary change in Helena's attitude towards Jimmy and she decides to leave him. Once Helena's arrival inspires Alison to leave Jimmy for a certain period of time and in her absence from Jimmy she understands what suffering means to him. She also realizes the need of her husband in her life. This understanding results in the reunion of them. And the reconciliation has been possible for the exit of Helena from Jimmy's life. The withdrawal of Helena has been possible because of Alison's return. So the arrival and departure of Helena are inter-related to the departure and arrival of Alison.

Now Alison's place is taken by Helena. It is beyond Alison's imagination that Helena can replace her in Jimmy's life. Her attention moves from hatred to love for Jimmy though "Alison apparently never suspects Helena of malintentions and considers her as a good friend." (LBA) But she stays with "Jimmy 
not with rancour or disgust, but with love and passion." (LBA) Though she adapts herself to Jimmy's resentful comments about things she asks him to refrain from talking about religion and politics. It means she has not accepted all his ideas. Even then they get hopeful about their future relationship and Jimmy says: "I'll close that damned sweet-stall, and we'll start everything from scratch." (LBA) Helena also agrees with it and their repartee is interrupted by the sudden arrival of Alison, untidy and ill in Act III. The awakening of Helena's conscience after Alison's return is a vital psychological fact revealing the corking up of human minds.

Colonel Redfern: Colonel Redfern, Alison's father, a good-looking man of sixty who has returned to England after spending forty years in the army, primarily in India. When Alison became involved with Jimmy, the colonel did not oppose his wife in her efforts to break up the match. When he arrives to pick up Alison, he admits that he should have taken a stronger stand and even confesses a liking for Jimmy, who has the energy both the colonel and Alison lack. In his generosity and his decency, the colonel symbolizes the best of the old order. His appearance in the play, so unlike Jimmy's caricature of him, casts doubt on Jimmy's clever but stereotype-based pronouncements. 


\section{Dr. Afaf Yousuf Abdulgadir Alkhidir}

Colonel represents the generations that came before the age of the "angry young man" whose identities were intertwined with and derived from the idealised version of Britain when she ruled the waves but are now struggling to come to terms with the state at which Britain is in from 1945 to the late 1950s. The Colonel depicts this in the play through impassioned speeches littered with extended metaphors and reflective imagery, notably the speech in which he analogises himself as an "old plant left over from the Edwardian Wilderness." This is strategically located directly after Jimmy Porter enacting the "angry almost hysterical often selfpitying young man who finds society cruel, unjust and his own world a chaos" as for Evans describes him, to the fullest extent. This allows the "old plant" metaphor to be dramatized to the audience prior to its actual use and thus allows them to take note of the extent British society has changed from the age of British imperialism to the beginning of an era where the authority of both the Colonel and Britain has "lately become less and less unquestionable", stated in the stage directions leading to the entrance of Colonel Redfern with his opening line admitting how this is "all beyond" him.

The "old plant" metaphor in conjunction with symbolism of British supremacy as the sun, shows how the Colonel defines his identity in British imperialism and therefore, fails to nurture and 
develop his own identity without it just as a plant fails to grow without sunlight. The contrast between the soft consonants and royal imagery used in the former and the repetition of harsh plosives in the latter highlights the superiority complex and unwarranted pride of the Colonel in seeing the governance of Britain over a country as a necessary evil for less economically developed countries.

Jimmy is the character of that era who ridicules his fatherin-law for being an old "Edwardian." This Edwardian Age is a reference to the reign of King Edward VII in Great Britain, a brief period at the beginning of the 20th century where a fashionable British elite influenced the art and fashions of continental Europe. Jimmy, however, is also in many ways a sentimental Edwardian. He views himself as a descendant of this more fashionable age, stuck in a time in which the world around him does not understand his passions and motivations. In comparison, the American Age is "dreary," meaning that the fashion and culture of this previous age has been wiped away by the rise of America as a great world superpower.

"If you've no world of your own, it's rather pleasant to regret the passing of someone else's. I must be getting sentimental. But I must say it's pretty dreary living in the American Age -unless you're an American of course." (Look Back in Anger, 15.) 


\section{Result And Discussion}

The characters in 'Look Back in Anger' are the products of the post world war II. They had the impact of two big revolutions like democracy and technology on their lives which is reflecting in their behaviour. The play is revolving around five characters wherein the conversation and attitude towards each other is the mixture of uncertainty, confusion, and traumatic situation developed in that period. It is depicted through the characters that the common man was facing the trauma of existentialism. The feelings of lack of identity were developing in general. The feelings of faithlessness among each other and with the environment were the substantial theme of the literature, culture and society.

The appraisal of the character of Jimmy Porter proves that Jimmy Porter, the protagonist of "Look Back in Anger" by "Osborne" was a dissatisfied, disillusioned and hopeless "angry young man" of "post II World War generation". He was in search of his identity in a society that was completely aggressive to his view point. This unsuccessful struggle to find out identity makes him angry and alienated to society, religion and his wife too. (Falak Naaz \& Anila jameel, 2015).

Allison is cultured, beautiful, tall and young woman from an upper middle class background. She bears all the cruelty, misbehaviour of Jimmy along with the poverty. Jimmy's 
treatment with Alison was the result of his hatred towards upper middle class. Eventually, every action of Alison was the cause of raising Jimmy's anger. Therefore, Alison was the biggest Victim in the play. Somehow Alison was indifferent towards Jimmy as a wife which reflects her immaturity and lack of handling relationships. Salma Haque (2014), has analysed that throughout the play Alison is portrayed as a tortured soul who sometimes has increased her troubles for her lack of insight, tact and maturity about human relationship. But Jimmy undeniably plays an important part in her sufferings. Fate also has major role to make her a perpetual sufferer. After their reunion, in Cliffe s absence, Jimmy will be encouraged to make piercing remarks and will make her life a nightmare again as: “... in the end she accepts her role as the dominated partner ... crawlingee (Carnal, 130).

The play 'Look Back in Anger' becomes the combination of the extreme behaviour of Alison-Jimmy and normal humane attitude of Cliff- Helena. Cliff and Helena are also the products of the same period; facing the same challenges in the political, social, technical and economical situations of England. The attitude of Cliff and Helena shows that the revolutions had not left a big impact on their behaviour or they were able to cope up with. Though both are almost from the same back ground like Cliff from Jimmy's background and Helena from middle class background. Professionally, she was a model. They both are 


\section{Dr. Afaf Yousuf Abdulgadir Alkhidir}

disturbed seeing the life of the married couple and tried to reconcile the situation. Being a young woman Helena got attracted towards Jimmy but at the end she could maintain her dignity and honour. At the same time Cliff remained quite normal and understanding throughout the play.

Colonel Redfern was from the previous generation and living present generation too. From the presentation of the character of Redfern, it is evident that the previous generation is not ready to accept the reality of transformation but they were still living in the amusement of the past glory of England.

Thus, the play 'Look Back in Anger' has depicted three different types of behaviour in England after the Second World War. Or we can say how the changes and challenges in England impacted of the behaviour of people in England. John Osborne has beautifully presented three categories of the people. First category included the people who were rebels, uncertain of their future, seeking identity and fighting for their existence. The second category was the group of people who accepted the changes and maintaining their dignity in the changing situations. Third category was the generation of the people who had seen the glory of England. They were not ready to come out of the dream world and face the reality. But, predominantly, the play is moving around the 'angry young man' behaviour of the characters. This 
creates a canvas of unsatisfied generation of that period reflecting through the behaviour of the characters. "I suppose people of our generation aren't able to die for good causes any longer. We had all that done for us, in the thirties and the forties, when we were still kids. ...There aren't any good, brave causes left." (Look Back in Anger, 84).

\section{Conclusion:}

The characters in Look Back in Anger are the reflection of the period of 1950-60. They are the production of the era where they are in search of their identity. This was modern man's existential problems: lack of identity, uncertainty to the self and to environment, pain of being alive in a meaningless universe, isolation and break down of communication. The behaviour of the characters in the play is not independent but it is the impact of the situation. As Jimmy Porter was an educated rebel from the working class society. He is always full of doubts with the attitude of upper middle class. This reflects from his attitude and behaviour with his wife and her parents. The behaviour of silence and keeping calm of Alison was the result of abusing behaviour of Jimmy. Lewis Cliff was an understanding man from working class society. He understands Jimmy and his frustration also he has sympathy with Alison. He wants to bring peace in their married life. Helena was an intelligent and outspoken and trustworthy friend of Alison. She could not tolerate Jimmy's abusing 


\section{Dr. Afaf Yousuf Abdulgadir Alkhidir}

behaviour with Alison and wanted to teach him a lesson. But in doing so, unknowingly she got attracted towards Jimmy which she informed Alison open heartedly. But on Alison's coming back, she maintained her dignity and left Jimmy. Though, she had a chance to stay with him. Colonel Redfern was not happy with Jimmy and Alison's marriage. However, he was impressed with Jimmy. He was still living in the allusion of the glory of England which reflects from his behaviour and attitude. Therefore, the characters and their behaviour give a direction to the play to go forward.

\section{Recommendations}

Though lot of research has been done on comparing characters of LBA in different perspectives but, in my view, further research can be done on:

- An appraisal to the behaviour of Cliff and Helena when both had the same intention to reconcile the life of Porters.

- The thought process and amusing behaviour of the previous generation who is living this generation too.

- Childhood of Jimmy Porter

- Cliff's simplicity, and his sympathetic attitude towards Alison.

- Why Helena not got attracted towards Cliff though he was an obvious option.

- Unstable attitude of Helena . 


\section{An Appraisal of the Behaviour of the Characters}

in Look Back in Anger

\section{Reference}

- Athanason, Arthor Nicholas "John Osborne" in concise Dictionary of British Library Biography Valume7. Writers after world war 11, 19451960 Gate, 1992 pp 231-54.

- Barker John a review of Look Back in Anger in Daily Express, May 9, 1956.

- Bilbngton Michae a review of Look Back in Anger in Guadian, Jine 8, 1989.

- Chattaraji Mouli: The Angry Young Jimmy Porter, Kitchen Sink Realism in John Osborne's Look Back in Anger and its relevance in the twentyfirst century society

- Coveney, Michael a review of Look Back in anger in Financial Times, June 13, 1989.

- Elsom, John Post-war British Theatre, Routledge \& Kegan Paul, 1979, pp. 72-87.

- Elsom, John Post-war British Theater Criticism, Rouledge \& Kegan Paul 1981. Pp 74-80.

- Ferrar, Harold John Osborne, Columbia University Press 1973, pp 312,46 .

- Haque Salma: Helena Charles's Arrival and Departure in John Osborne's Play Look Back in Anger: A Study of Structure , IIUC STUDIES ISSN 1813-7733 Vol. - 4, December 2007 Published in April 2008 (p 41-48)

- Haque Salma: Alison Porter in Look Back in Anger: Is She Responsible for her Sufferings?

- IIUC STUDIES ISSN 1813-7733 Vol.- 10 \& 11, December 2014 (p 65$80)$. 


\section{Dr. Afaf Yousuf Abdulgadir Alkhidir}

- Hobso, Harold a review of Look Back in Anger in Sunday Times, May $13,1965$.

- Hope-Wallace Philip a review of Look Back in Anger in Machester Guardian May 10, 1956.

- Köseoğlu Berna: Discussions Of Social Class, Discrimination And Class Conflict In The Cherry Orchard And Look Back In Anger, Article

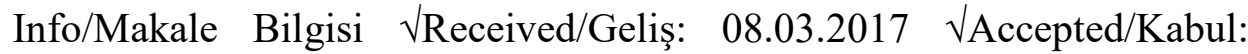
24.05.2017 DOİ:10.5505/pausbed.2017.49389

- Malcolm file on Osborne, Methuen 1988, pp 11-17.

- Mander, John, The Writer and Commitment, London, Secker \& Warburg Ltd., 1961.

- Naz Falak \& Jamil Aneela, An Analysis Of Identity Crisis Of Osborne's Character "Jimmy Porter" In "Look Back In Anger" British Journal of English Linguistics Vol.3, No.4, pp.20-24, September 2015.

- Paton, Maureen a review of Look back in Anger in Daily Express, June 8, 1989.

- Shulman, Milton A review of Look back in anger in evening standard, May 9, 1956.

- Symth, Darman a regview of Look Back in anger in Independent June 10, 1989.

- Taylor, John Russell Anger and After: A Guide to the New British Drama, London, Methuen \& Co. Ltd., Hill \& Wang Inc., 1978.

- Tynan, Kenneth a review of Look Back in anger in observer, May 13, 1956.

- Wilson, cecil, a review of Look Back in anger in Daily Mail May 9, 1956. 